\title{
Foreign Direct Investment, Trade Openness and Economic Growth: Evidence from Ghana
}

\author{
Emmanuel Nketiah $^{1 *}$, Xiang Cai ${ }^{1}$, Mavis Adjei ${ }^{1}$, Bekoe Bernard Boamah ${ }^{2}$ \\ ${ }^{1}$ School of Business, Nanjing University of Information Science \& Technology, Nanjing, China \\ ${ }^{2}$ Business School, Hohai University, Nanjing, China \\ Email: ^nketiah888@hotmail.com,61894147@qq.com, oseikai@hotmail.com, bekoe92@yahoo.com
}

How to cite this paper: Nketiah, E., Cai, X., Adjei, M. and Boamah, B.B. (2020) Foreign Direct Investment, Trade Openness and Economic Growth: Evidence from Ghana. Open Journal of Business and Management, 8, 39-55.

https://doi.org/10.4236/ojbm.2020.81003

Received: October 16, 2019

Accepted: November 25, 2019

Published: November 28, 2019

Copyright $\odot 2020$ by author(s) and Scientific Research Publishing Inc. This work is licensed under the Creative Commons Attribution International License (CC BY 4.0).

http://creativecommons.org/licenses/by/4.0/

\begin{abstract}
This article investigates the relationship among foreign direct investment, trade openness and economic growth in Ghana taking the period of post-liberalization covering 1975-2017. The Augmented Dickey-Fuller (ADF) test for unit root, regression analysis, descriptive analysis, and Pearson correlation was used to investigate the relationships. ADF test for unit root result shows all variables to be integrated of order one, that is they are stationary after the first difference. The study extracted and used secondary data sources derived from the World Development Indicators (WDI) of the World Bank and Bank of Ghana website over the period 1975-2017. The study proxied foreign direct investment, inflation, and trade openness were used as an independent indicator while GDP growth (annual \%) was the dependent indicator. Using the Ordinary Least Squares (OLS) estimator, the study revealed that trade openness is the main factor affecting GDP growth (annual \%) in Ghana. Also, the study finds that foreign direct investment and Inflation had $(-$, or +$)$ impact but were not statistically significant on GDP growth (annual \%). Therefore, the study concludes by recommending robust measures to enhance trade openness in terms of encouraging exports and inflow of FDI through the creation of an enabling and friendly environment to do business for output growth dynamics in Ghana.
\end{abstract}

\section{Keywords}

Foreign Direct Investment, Trade Openness, Economic Growth and Inflation

\section{Introduction}

In the period of liberalization and globalization, trade openness and foreign direct investment (FDI) have developed as major incentives to economic growth 
and development in developing economies. FDI serves as an important source of funds for domestic investment thus, promoting capital formation in the host country [1]. Likewise, FDI, trade openness has performed a crucial role in shaping the stages of economic development over many years in developing countries. Investment Policy for Sustainable Development by United Nations Conference on Trade and Development (2012) quoted FDI is a driver of sustainable development while trade openness is highlighted by World Trade Organization as another driver for sustainable development especially for developing countries. According to World Investment Report by the World Trade Organization and United Nations Conference on Trade and Development [2], the roles of FDI and trade openness have expanded to include not just the effect on growth but also on income distribution and environmental quality which are the three main pillars of sustainable development set by the Commission on Sustainable Development of the United Nations.

The endogenous growth theory of the 1980s considered technological progress and FDI to have permanent growth effects in the host country through technology transfer and spillover [3]. In an increasingly globalized economy, FDI and international trade, especially through exports and imports, enhance competition in the international markets and technology transfer and thus promote economic growth [4] [5]. Conversely, growth also has effects on trade [6]. The export expansion brings greater economies of scale, productivity and removes foreign exchange constraints, thereby providing greater access to international markets [7] while FDI can add-on knowledge and technology transfer and increase job opportunities thus, boosting overall growth in the host country.

The purpose of this article is to investigate and evaluate the impact of FDI and trade openness on economic growth within the multivariate framework in Ghana taking the period after post-liberalization. The study of FDI inflows and trade openness and their impact on economic growth and development is vital, given its relevance in explaining growth dynamics in Ghana and other developing economies. Since the start of the economic liberation policy in the 1990s, the volume of trade and FDI inflows have been on the increase affecting the economic growth of Ghana. Figure 1 shows the growth trend of FDI, export, and import as a percentage of GDP for the period 1975-2017.

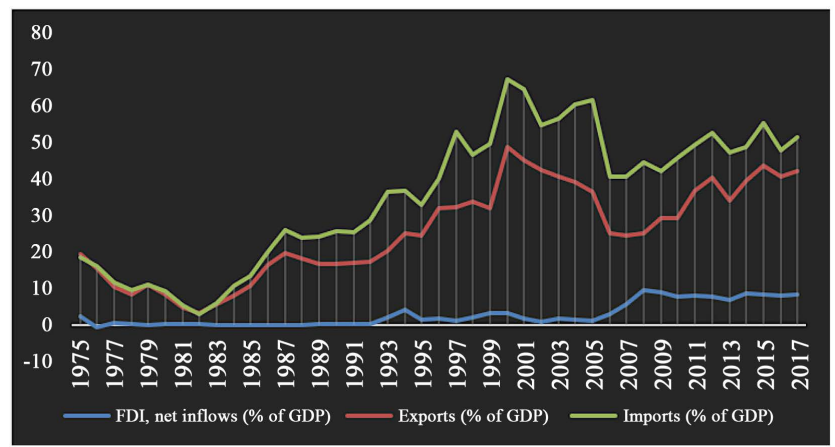

Figure 1. Trend of FDI, export, and import as a percentage (\%) of GDP. 
In Figure 1, it is demonstrated that FDI inflows in 1976 were very low it was around -0.66 percent of GDP which increases to 4.28 percent in 1994 and then increased to 9.5 percent in 2008. The rate of growth of FDI inflows has been increasing and decreasing thereafter and reached 8.7 percent in 2014 and further decline to 8.3 percent in 2017. Similarly, the rate of growth of export shows an increasing trend, thus export rate increased with fluctuations from 19.4 percent in 1975 to 48.8 percent in 2000 as a percentage of GDP. The growth rate of export continues to fall and reached 24.5 percent in 2007 and then rise to 43.9 percent in 2015 and decline to 42.3 in 2017.

Furthermore, the import growth rate is also observed a similar trend as that of export; thus, the percentage of import increases from 18.4 percent in 1975 to 52.9 percent in 1997 and reached the peak at 67.3 percent in 2000 and decline to 62 percent in the year 2017.

The FDI plots show generally an upward trend with fluctuations. The trade openness (export and import) plots exhibit a downward trend with fluctuations from 1975-2017 after which it started to trend upwards. This suggests that the movements of the plots indicate that the mean and the variance of both FDI and trade openness (export and import) data are changing over time. This means that the mean is non-constant, and the variance is unstable.

Figure 2 reflects the annual rate of GDP growth (annual \%) during the period of post-liberalization. It demonstrates that Ghana had the lowest GDP growth rate in the initial period of reform around -12.43 percent in 1975 . But thereafter, it has increased to 8.48 percent in 1978 and then decline to -6.92 percent in 1982. The annual growth rate increased to 8.6 percent in 1984 and then decline to 5.1 percent in 1985 and attained the highest growth of 14.1 percent in 2011 . Then the average annual growth rate declined sharply to 3.8 percent in the year 2017. Political instability and economic mismanagement from the mid 1960's to the early 1980's [8] requiring the prompt intervention of the IMF's economic recovery program in the 1980s were among the few reasons for the deterioration of the economy and apparent fluctuations. Moreover, the decline in crude oil prices valuing the total crude oil export revenue of Ghana at $\$ 3.12$ billion in 2017 , compared to that of 2018 ( $\$ 4.75$ billion) were among the factors causing the sharp decline in economic growth in Ghana in 2017 [9]. Overall the average annual growth was 3.78 percent during the reform period.

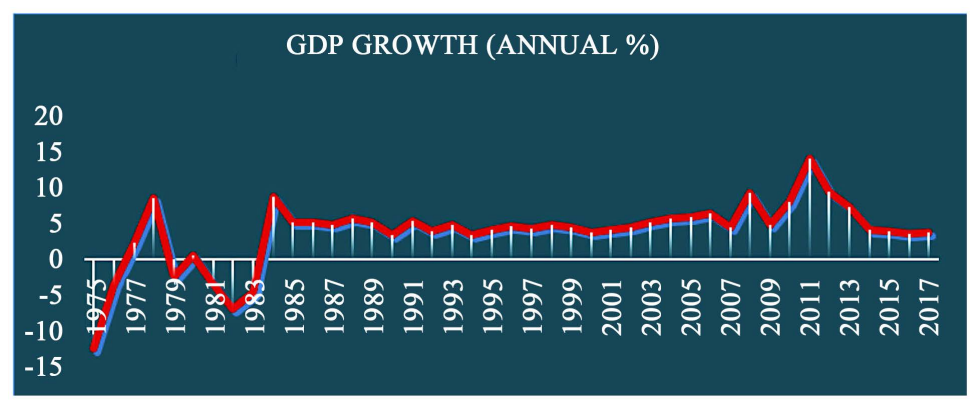

Figure 2. GDP growth (annual \%). 
The GDP growth (annual \%) plots show generally an upward and downward trending with fluctuations. This suggests that the movements of the plots indicate that the mean and the variance of GDP growth (annual \%) data are changing over time. This means that the mean is non-constant, and the variance is unstable.

In terms of GDP growth, Ghana has become one of the fastest-growing economies in the world in recent years. Given this, many researchers have argued that FDI and trade (export plus import), inter alia, play a significant role in achieving growth and development. As FDI and trade represent the most important variables in explaining growth dynamics, understanding the causal connections between these phenomena is important for developing strategies in Ghana and other developing countries. Therefore, this study is guided by the following specific research objectives:

1) To examine the interrelationship among FDI, trade openness and economic growth in Ghana.

2) To estimate the dynamics of FDI, trade openness and economic growth in Ghana using the recent econometric technique.

The rest of the article is structured as follows: Section 2 is a brief overview of Literature Review and Section 3 includes the relationship of FDI, domestic investment and economic growth in Ghana. Section 4 deals with data sources and methodology and results analysis. Finally, summary, conclusion, and policy implications are presented in Part 5.

\section{Literature Review}

\subsection{A Brief Overview of Literature (Theoretical Essence of the Study)}

Over the last three years, there have been different elements of theoretical and empirical studies meant at investigating the relationship among macroeconomic variables including FDI and openness to trade. The general theoretical literature on international trade advocates that trade contributes positively to the long-term growth prospects of a country [10]. The new growth theories indicate that trade openness increases economic growth by enhancing the scale of spillover [11]. There is also accumulated empirical evidence signifying that trade openness has led to increased efficiency, productivity, technology, and growth in both developed and developing countries [12] [13], The World Bank, [14]. Similarly, literature has proposed that FDI may lead to the transfer of technology, economic transformation, technological progress and human capital development [15] [16]. Furthermore, the literature reflects FDI inflows to be particularly important for developing countries as it provides productive capital necessary for performing economic activities [17]. Thus, FDI complements the domestic capital stock and enhances the production capabilities of the national economy in the long run [1] [18]. It aids to overcome the shortage of capital in host countries through the flows of FDI funds to high-risk areas or new industries that are 
with limited domestic investment [19]. There may arise other possible positive spillovers when multinational enterprises (MNEs) have vertical inter-firm linkages with domestic firms or have a subnational cluster of interrelated activities, resulting in increased domestic entrepreneurship in a host economy. Besides the above channels, FDI can also contribute to economic growth through increased exports from the host country when MNEs locate in the host-country for export activity.

There are many empirical studies investigating the long-run relationships among economic openness, trade and growth based on a time-series framework and co-integration analysis. For example, [20], using a large sample of 158 countries over the period 1970-2009, conclude that there is a significant positive causal long-term effect running from trade openness to economic growth and vice versa. Yanikkaya [21] finds, using various trade liberalization indices for 120 countries over the period 1970-1999 that trade has a positive impact on real GDP per capita while [22] used the data of 61 countries, and finds that greater trade openness is positively related to economic growth and real income in case of developing countries but it is negatively linked to economic growth in case of developing countries.

Above and beyond trade openness, some studies also examine explicitly the long-run causal relationship between FDI and growth. More specifically, the empirical evidence points out that in Southeast Asian countries FDI contributes significantly to GDP growth [23]. Besides, the studies that included trade-related measures and FDI simultaneously to investigate long-run growth effects reveal the presence of intricate interrelationships [24]. It indicates that different patterns and causality relations can arise. For instance, FDI might cause trade (exports and imports), which causes economic growth without a direct growth effect of FDI, or FDI and exports both having only direct effects on growth, or other interdependencies.

Dutta, et al. [25] examined the causal relationship among foreign direct investment, domestic investment, trade openness and economic growth in Bangladesh over the period 1976-2014. The results found unidirectional causality running from foreign direct investment to growth, domestic investment to trade openness, growth to trade openness and bidirectional causality between domestic investment and growth and foreign direct investment and domestic investment.

Several studies have attempted to explore the interrelationship between FDI, trade openness and economic growth and the evidence has been mixed [26] [27]. Sharma [28] has noted that FDI bears statistically no significant impact on export performance in India although the coefficient of FDI has a positive sign and therefore, concludes that any linkage effect through the export-promotion channel is perhaps weak in the Indian context.

Hye and Lau [27] examine the link between trade openness and economic growth and find a negative and unstable impact of trade openness index on economic growth throughout the sample in the long run. Ved and Sudesh [29] 
examine the relationship between trade openness and economic growth in the case of India and found bidirectional causality among economic growth and trade openness indicators.

Thus, the literature shows that the results of the FDI inflows and trade openness impact on economic growth have been quite varied and inconclusive. The major factors responsible for these contradictions in the empirical studies include, inter alia, variances in data used, countries, data measurement and definitions, methodological approaches [1]. The varied views on the nexus between the variables indicate a literature gap, allowing us to develop more interest to further explore the relationship between FDI, trade openness and economic growth where few studies have been conducted. Specifically, not many studies have been attempted to identify the long-run co-integrated relationship between FDI, trade and economic growth in the context of Ghana. Therefore, the paper contributes to the existing literature using recent data and the relationship between the above variables in multivariate form by examining Ghana as a developing country.

\subsection{Relationship between Trade Openness, Economic Growth, and FDI}

Openness to trade is another important determinant of economic performance. Generally, the market or trade potential of a country is represented by the level of GDP in the country which attracts foreign investment, thus creating further opportunities for more trade. Openness to trade aids the transfer of technology and knowledge into the economy, which contributes to the exploitation of comparative advantage through increasing exposure to competition. Also, liberalization increases specialization and division of labor, which in turn raises productivity and export capability of the country, thus improving overall economic performance. Hence it can be argued that there is a strong positive link between openness and economic growth, based on sound theoretical grounds. There is an enormous amount of empirical literature that has explored this linkage in practice. For instance, according to [30] countries with more trade openness have a relatively higher economic growth compared to those which are less open. Similar opinions were shared by [31] [32]. Nevertheless, the results are not conclusive. There have been several studies that highlight the methodological flaws and limitations of studies that show the positive relationship between trade and growth. Trade liberalization may harm the process of economic growth through various forms of macroeconomic stability including trade deterioration and balance of payment crisis. Therefore, the direction of causality between trade openness and economic growth is ambiguous.

FDI is likely to have a direct or indirect effect on growth through trade. Hence the causal relationship between trade, economic growth, and FDI is mutual. Trade openness in the form of FDI has emerged as one of the main issues in explaining the growth phenomena in developing countries [33] [34]. FDI is expected to have an impact on trade flows because it is mainly driven by two in- 
centives to provide resources to local markets or benefit from low-cost factors of production in the host country [35]. It would be a positive impact if the country is export-oriented, and vice-versa. By applying Granger causality test to examine the direction of causalities between the FDI, trade, and growth using time series data between 1970-2003 for several countries, they have found that for most countries there is no significant Granger causality between FDI and GDP, whereas that for GDP and trade varies in different countries.

However, their results have been far from conclusive. Some empirical pieces of evidence also provided conflicting results. Looking into data from 1980 to 2007 for Cote d'Ivoire, [36] used the bounds testing cointegration approach and the VAR Granger causality/Block Exogeneity Wald tests and revealed that there is a unidirectional long-run relationship between FDI, trade openness and output; and the causality runs from FDI, trade openness to output and from output, FDI to trade openness. Both trade openness and FDI are significant factors of output growth in Cote d'Ivoire. Conversely, Acaravci and Ozturk [33] used the ADRL and Granger causality test on the quarterly data from 1994 to 2008 to examine the long-term relationship between FDI, export and economic growth for Bulgaria, the Czech Republic, Estonia, Hungary, Latvia, Lithuania, Poland, Romania, Slovakia, and Slovenia. The results have shown the existence of long-term co-integration in only the Czech Republic, Slovakia, Poland, and Latvia. They have also completed that the effect of FDI on growth outweighed that of export in these countries.

\subsubsection{Foreign Direct Investment in Ghana}

Foreign direct investment (FDI) plays a major role in achieving rapid economic development in developing countries [37]. Among the developing countries, some countries, like Ghana, Nigeria, and Sudan are the main FDI recipient countries because of alluring certain factors. Ghana has a long history of cocoa, gold, and other mineral resources. According to the Ghana Chamber of Mines (GCM), from 1493 to 2017, an estimated gold produced amount to 4000 metric tons. Apart from South Africa, Ghana is the second-largest producer of gold in Africa. As such, the country has been making efforts to attract foreign direct investment (FDI) through these resources [38]. The efforts include implementing the Economic Recovery Programme, Structural Adjustment Programme, and instituting Ghana Investment Promotion Center (GIPC). In this, the government of Ghana provides useful protection and guarantees to foreign investors through the GIPC Act by permitting free transferability of net profits and dividends that are attributable to investments in Ghana. GIPC [39] reports that foreign direct investment components of the estimated value of registered projects amount to US\$2954.61 million in the first quarter of 2017 with Netherlands being first, followed by India and the UK, and China being fourth.

Faiza et al. [40] also investigated the impact on foreign direct investment due to the growth and inflation of Pakistan using annual time series data from 1990 to 2011. FDI is taken as a dependent variable whereas GDP and inflation are 
taken as independent variables. To assess the impact of FDI on growth and inflation time series data regression was used. The result suggests that foreign direct investment relates positively to inflation and growth. As seen from the two studies, the conflicting results are due to the different estimation techniques. Whereas Mehmet employed the Johansen cointegration test, [40] engaged the multiple regression analysis. Also, the former added Trade as a control variable to prevent omission bias. Similarly, Taiwo [41] examined the long run cointegration relationship between inflation, investment, and growth in Nigeria over the period 1980 to 2006. The results from the ordinary least squares indicated that inflation relates negatively and positively with growth. Both studies fail to check for causality between the inflation, FDI and growth.

According to the Ghana Free Zones Authority (GFZA), as of 2017, Ghana placed the 7th position in the league of countries that attract FDI in Africa obtaining 43 projects out of 716 FDI projects that flowed to Africa [42]. Various recommendations are provided to support existing efforts for attracting foreign direct investment in Ghana. For instance, Wafure and Abu [43] recommend policies for expanding Ghana's GDP and reducing government interference in economic activities. Owusu [44] makes a call for an enabling socio-economic environment through Ghana Free Zones Authority and Ghana Investment Promotion Centre. Notwithstanding Majavu and Kapingura, [45] point outthat there is a need for mobilizing domestic savings, given that events outside a host country have critical effects on the flow of foreign direct investment.

\subsubsection{Gross Domestic Product, GDP}

High economic growth serves as an indicator of development potential and provides opportunities for profit-making [46]. Dondashe and Phiri [47] indicate that there is a positively and significantly relationship between GDP and foreign direct investment. Also, Ebiringa and Emeh [48] suggest that GDP put a long-term positive effect on foreign direct investment flows. Moreover, Wasseja and Mwenda [49] identify GDP as a significant determinant of foreign direct investment inflows.

\subsubsection{Inflation}

Mehmet [50] explored the association between growth, FDI, trade, and inflation in turkey using annual time series data over the period from 1970 to 2008. The results of the Johansen cointegration test revealed that inflation and FDI are positively related to growth. Ebiringa and Emeh [48] argue that macroeconomic uncertainties, like inflation, imply higher costs for firms, as such lead to incurring additional expenditure towards ensuring protection against risks. Ali et al. [51] propose a negatively significant relationship between inflation and FDI inflow. Djokoto and Dzeha [52] support [49] stand and conclude that high inflation leads to low foreign direct investment inflows. (Adi et al. [45]; Ohazulike, [53]) also, allude to the fact that inflation has a significant negative effect on FDI attraction to an economy. 
Omankhanlen [54] explored the effect of the exchange rate and inflation on foreign direct investment and its relationship with economic growth in Nigeria using annual time series data over the period 1980 to 2009. Government expenditure and gross fixed capital formation were added as control variables. A linear regression analysis was used on the thirty-year data to determine the relationship between inflation, exchange rate, FDI inflows, and economic growth.

\subsubsection{Trade Openness}

A country's degree of openness to internal trade is relevant for attracting foreign direct investment [46]. Trade openness is determined as the ratio of imports plus exports to gross domestic product. The higher degree of openness of an economy shows more open and liberalize economic and trade regime. As a result, trade openness harms FDI inflows. Dondashe and Phiri [47] note that trade openness to contribute to attracting foreign direct investment into a country. Owusu [44] suggests that trade liberalization is an insignificant determinant of foreign direct investment inflows. It found that a more friendly environment for enterprises is more successful in obtaining FDI [37].

\section{Data and Methodology}

To explore the main objective through examining the relationship among foreign direct investment, trade openness and economic growth, this study employs the Ghanaians annual time series from 1975-2017 from World Development Indicators (WDI). The reason for selecting the period was based on data availability. The data set on the variables, FDI and trade openness (TOP) are sourced from World Development Indicators (WDI, 2019) and Gross Domestic Product (GDP) data series is extracted from the Reserve Bank of Ghana. The variables used in the model are measured as follows: we used economic growth proxied by real GDP per capita as the dependent variable.

The model specification follows the growth function where the level of economic performance is conjectured to be sensitive to foreign capital and trade flows in the presence of strong institutional quality [55]. The independent variables include FDI measured as the net inflow of foreign direct investment as a share of GDP and trade measured as total trade as a share of GDP. The variable trade openness is proxied by export plus import as a percentage of GDP, economic growth is proxied by GDP and FDI is net inflows (\% of GDP). The data analysis and statistical software used was STATA 14 [56].

The variable trade openness is proxied by export plus import as a percentage of GDP, economic growth is proxied by GDP and FDI is net inflows (\% of GDP). Using the Ordinary Least Squares (OLS) estimator, the study established GDP growth (annual \%), foreign direct investment, inflation, and trade openness'. The Augmented Dickey-Fuller (ADF) test for unit root is applied to test for stationarity of the series. Statistical tests like test and F-test are applied when necessary to examine the significance of the estimated results.

To examine the relationship between the variables, the model is specified as: 


$$
\begin{gathered}
y_{1}=\beta_{0}+\beta_{1} x_{1 i}+\beta_{2} x_{2 i}+\cdots+\beta_{n} x_{n i}+\varepsilon_{i} \\
\mathrm{GDP}_{t}=\beta_{0}+\beta_{1} \mathrm{FDI}_{t}+\beta_{2} \mathrm{INFLA}_{t}+\beta_{3} \mathrm{TOP}_{t}+\varepsilon_{t}
\end{gathered}
$$

where,

GDP $=$ Gross Domestic Product, a proxy for economic growth.

FDI $=$ Foreign Direct Investment Inflows.

TOP $=$ Trade openness, i.e., export plus import as percentage of GDP.

INFLA = Inflation.

\section{Results and Analysis}

\subsection{Descriptive Statistics}

Table 1 presents the outcome of the estimation in which the results are based on mean, standard deviation, minimum, maximum for the selected dependent an independent variable. The data for the study analysis were retrieved from the World Development Indicators (WDI) from the World Bank with data from 1975-2017 (i.e. 43 years).

\subsection{Diagnostic Test}

\subsubsection{Unit Test}

Figure 3 shows the time series plot for natural logarithm transformation (a) and the time series plot for first difference transformation (b) of Gross Domestic Product, proxy for economic growth (GDP), Foreign Direct Investment Inflows(FDI), Trade openness, i.e., export plus import as percentage of GDP (TOP)and Inflation (INFLA) from 1975-2017 based on STATA output. All variables were transformed into natural logarithms.

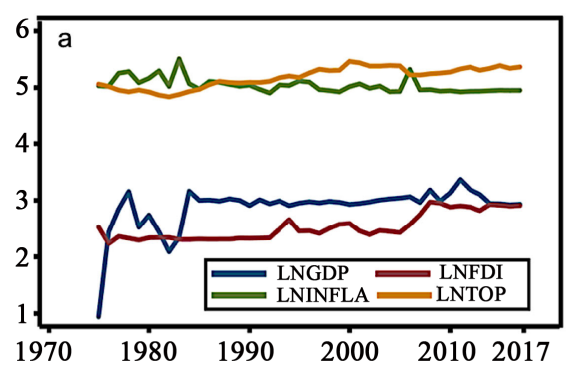

(a)

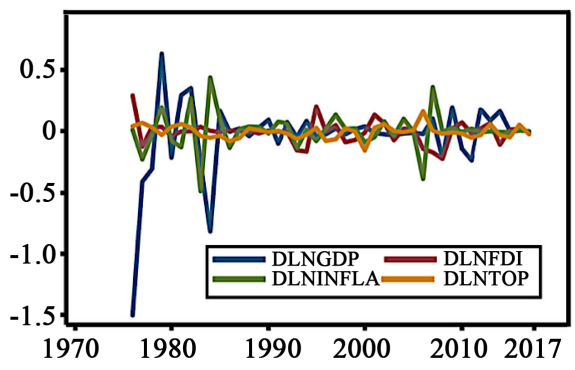

(b)

Figure 3. (a) ADF test at levels from the year 1975 to 2017; (b) ADF test at first difference from 1975-2017.

Table 1. Descriptive Statistics for selected dependent and explanatory variables.

\begin{tabular}{cccccc}
\hline Variable & Observations & Mean & Standard deviation & Minimum & Maximum \\
\hline GDP & 43 & 3.774 & 4.580 & -12.432 & 14.046 \\
FDI & 43 & 2.889 & 3.280 & -0.660 & 9.517 \\
TOP & 43 & 32.048 & 22.380 & 11.150 & 123.061 \\
INFLA & 43 & 60.735 & 31.198 & 6.320 & 116.048 \\
\hline
\end{tabular}


The GDP, FDI, trade openness and inflation plots show generally an upward and downward trending with fluctuations. This suggest that the movements of the plots indicate that the means and the variances of Gross Domestic Product, proxy for economic growth (GDP), Foreign Direct Investment Inflows (FDI), Trade openness, i.e., export plus import as percentage of GDP (TOP)and Inflation (INFLA) data are changing over time. This means that the mean is non-constant, and the variance is unstable. For the stationarity of the data, the first differencing (i.e. performing a unit test) of the natural logarithm of Gross Domestic Product, proxy for economic growth (GDP), Foreign Direct Investment Inflows (FDI), Trade openness, i.e., export plus import as a percentage of GDP and Inflation needed to be calculated and employed in our analysis as adopted in [57].

\subsubsection{Multicollinearity Test}

While a multicollinearity diagnostic is reflected, pairwise correlation coefficients between predictors and VIF are the most common tools for inspection used by statisticians and epidemiologists. Numerous investigators use correlation coefficients cut-offs of 0.5 and above [58] but the most typical cut-off is 0.80 [59] Although VIF greater than 5 or VIF greater than 10. Kutner [60] are recommended for identifying multicollinearity, there is no universal understanding as to what the cut-off based on values of VIF should be used to identify multicollinearity. If the VIF is more than 10, then there exist multicollinearity and vice versa. The results showed that the null hypothesis is rejected, which means that there is no sign of multicollinearity (Table 2).

\subsubsection{Pearson Correlation Test}

The null hypothesis is that there is no relationship between Gross Domestic Product, a proxy for economic growth and the explanatory variables.

The results from Table 3 show that inflation (INFLA) have a moderately negative $(\mathrm{P}=2.41)$ with Gross Domestic Product, a proxy for economic growth. The

Table 2. Multicollinearity results for all variables.

\begin{tabular}{ccc}
\hline Variable & VIF & $1 /$ VIF \\
\hline TOP & 2.03 & 0.494 \\
FDI & 1.67 & 0.600 \\
INFLA & 1.58 & 0.632 \\
Mean VIF & & 1.76 \\
\hline
\end{tabular}

Table 3. Pearson correlation among explanatory variables used in the regression analysis.

\begin{tabular}{ccccc}
\hline Variables & GDP & FDI & INFLA & TOP \\
\hline GDP & 1.000 & & & \\
FDI & 0.256 & 1.000 & & \\
INFLA & -0.241 & -0.463 & 1.000 & \\
TOP & 0.417 & 0.6218 & -0.594 & 1.000 \\
\hline
\end{tabular}


negative prior supports the related theory which states that the more opened an economy the higher the rate at which the Gross Domestic Product, a proxy for economic growth will appreciate. The remaining variables showed a weak relationship with Gross Domestic Product, a proxy for economic growth. For example, trade openness and foreign direct investment showed a very weak but positive relationship with Gross Domestic Product, a proxy for economic growth. The reason is that a large debt encourages inflation, and if inflation is high, the debt will be serviced and ultimately paid off with cheaper real dollars in the future.

\subsubsection{Regression Result Analysis}

Table 4 shows the regression coefficients for the model estimating the impact of selected factors on economic growth (GDP) using Pooled OLS. From the Table, the model shows that trade openness (TOP) is significant at 5\% level in Pooled OLS estimation. This suggests that trade openness is a good explanatory variable for determinants of Gross Domestic Product, a proxy for economic growth (GDP), in Ghana. The coefficient on the explanatory variables is negative (except FDI and INFLA) and shown in Equation (3).

The model for the GDP growth

$$
\mathrm{GDP}_{t}=-1.990+4.262 \mathrm{FDI}_{t}-0.47 \mathrm{INFLA}_{t}+0.643+\varepsilon_{t}
$$

\section{Conclusions and Policy Implications}

This article investigated the relationship among foreign direct investment, trade openness and economic growth in Ghana for the period 1975-2017. The results indicated that the ADF test for the unit root of time series showed all variables non-stationary at the level. To analyze the determinants of GDP growth in Ghana, the Ordinary Least Square method was chosen to the other techniques, because of its several advantages over those alternative techniques. In the application of the methodology, the study started by analyzing the time series of the

Table 4. Regression coefficients for the model estimating the determinants of GDP growth (annual \%) in Ghana using Pooled Least Squares (OLS).

\begin{tabular}{ccccc}
\hline GDP & Coefficient & Standard Error & t-statistic & P-value $(\mathbf{P}<0.05)$ \\
\hline C & -1.990 & 4.262 & -0.47 & 0.643 \\
FDI & -0.007 & 0.306 & -0.02 & 0.982 \\
INFLA & 0.029 & 0.550 & 0.05 & 0.959 \\
TOP & 0.915 & 0.446 & 2.05 & $\mathbf{0 . 0 4 7 ^ { * }}$ \\
Adjusted R-squared & & 0.110 & \\
R-squared & & 0.174 & \\
F-statistic & & 2.73 & \\
Prob (F-statistic) & & 0.0566 & \\
No of observations & & 43 \\
\hline
\end{tabular}

*Significance level at $95 \%$ Source Authors construct. 
data employing both Correlation and Multicollinearity tests as well as the overall significance of the model. The variables were found to possess a very low degree of collinearity. The correlation results showed that only one variable (trade openness) correlated moderately with GDP growth whereas the remaining showed weak correlation with GDP growth. The overall significance tests, on the other hand, show that F-test and adjusted R-squared in the model specifications provided evidence that the explanatory variables are jointly not equal to zero, therefore indicating a good fit of the model.

The research shows that foreign direct investment (FDI), inflation (INFLA) and trade openness (TOP), on average, have asymmetric effects with the positive impact of TOP while the negative impact of FDI and INFLA on economic growth. The study revealed that trade openness is the main factor affecting GDP growth (annual \%) in Ghana. Also, the study finds that foreign direct investment and Inflation had an impact but were not statistically significant on GDP growth (annual \%).

Based on the findings, this study concludes by recommending more trade openness in terms of encouraging exports and inflow of FDI through the creation of an enabling and friendly environment to do business for output growth dynamics in Ghana. And it was recommended that the government of Ghana should develop policies to increase openness of foreign trade for domestic enterprises to take part in the global economy fully. For future research, there is a need to employ a larger data size to carry out the same study to find whether GDP, FDI, TOP, and inflation would be statistically significant.

Further research about this study that separates the long-run and short-run estimation to ascertain the impact of present situation on future of the Ghanaian economy is recommended.

\section{Acknowledgements}

We extend our special gratitude to the developers, managers and funding agencies of World Bank Development indicators (WDI) for granting access to these essential datasets in accordance to their specific data use and citation policies.

\section{Conflicts of Interest}

The authors declare no conflicts of interest regarding the publication of this paper.

\section{References}

[1] Omisakin, O., Adeniyi, O. and Omojolaibi, A. (2009) Foreign Direct Investment, Trade Openness and Growth in Nigeria. Journal of Economic Theory, 3, 13-18.

[2] United Nations Conference on Trade and Development (2012) World Investment Report 2012: Towards a New Generation of Investment Policies. United Nations Publication, Geneva.

[3] Jayachandran, G. and Seilan, A. (2010) A Causal Relationship between Trade, Foreign Direct Investment and Economic Growth for India. International Research 
Journal of Finance and Economics, No. 42, 74-88.

[4] Grossman, G.M. and Helpman, E. (1991) Endogenous Innovation in the Theory of Growth. Journal of Economic Perspectives, 8, 23-44. https://doi.org/10.1257/jep.8.1.23

[5] Frankel, J.A. and Romer, D. (1999) Does Trade Cause Growth? The American Economic Review, 89, 379-399. https://doi.org/10.1257/aer.89.3.379

[6] Rodríguez, F.R. and Rodrik, D. (2000) Trade Policy and Economic Growth: A Skeptic's Guide to the Cross-National Evidence. NBER Macroeconomics Annual, 15, 261-338. https://doi.org/10.2307/3585399

[7] Dritsaki, M., Dritsaki, Ch. and Adamopoulos, A. (2004) A Causal Relationship between Trade, Foreign Direct Investment and Economic Growth for Greece. American Journal of Applied Sciences, 1, 230-235. https://doi.org/10.3844/ajassp.2004.230.235

[8] Acquaah, M. (2015) Determinants of Corporate Listings on Stock Markets in Sub-Saharan Africa: Evidence from Ghana. Emerging Markets Review, 22, 154-175. https://doi.org/10.1016/j.ememar.2014.10.002

[9] Bank of Ghana (2018) Bank of Ghana (2018) Annual Report. The Editorial Committee Bank of Ghana. https://www.bog.gov.gh/publications/annual-report

[10] Van den Berg, H. and Lewer, J.J. (2015) International Trade and Economic Growth. Routledge Publishing, New York.

[11] Romer, P.M. (1990) Endogenous Technological Change. Journal of Political Economy, 98, 71-102. https://doi.org/10.1086/261725

[12] Bhagwati, J.N. (1978) Foreign Trade Regimes and Economic Development: Anatomy and Consequences of Exchange Control Regimes, National Bureau of Economic Research. Ballinger Publishing Company, Cambridge.

[13] Markusen, J.R., Melvin, J.R., Kaempfer, W. and Maskus, K. (1995) International Trade: Theory and Evidence. McGraw-Hill Publishing, New York.

[14] World Bank (2015) The Role of Trade in Ending Poverty. World Bank Publications, Washington DC.

[15] Borensztein, E., Gregorio, D. and Lee, J.W. (1998) How Does Foreign Investment Affect Growth? Journal of International Economics, 45, 115-135. https://doi.org/10.1016/S0022-1996(97)00033-0

[16] De Mello, L.R. (1999) Foreign Direct Investment-Led Growth: Evidence from Time Series and Panel Data. Oxford Economic Papers, 51, 133-151. https://doi.org/10.1093/oep/51.1.133

[17] UNCTAD (2016) World Investment Report 2016: Investor Nationality: Policy Challenges. United Nations Conference on Trade and Development, United Nations, New York.

[18] Tang, S., Selvanathan, E.A. and Selvanathan, S. (2008) Foreign Direct Investment, Domestic Investment, and Economic Growth in China: A Time Series Analysis. UNU-WIDER Research Paper No. 2008/19. https://doi.org/10.1111/j.1467-9701.2008.01129.x

[19] Noorzoy, M.S. (1979) Flows of Direct Investment and Their Effects on Investment in Canada. Economic Letters, 2, 257-261. https://doi.org/10.1016/0165-1765(79)90032-6

[20] Gries, T. and Redlin, M. (2012) Trade Openness and Economic Growth: A Panel Causality Analysis. CIE Working Papers No. 52. Center for International Economics, University of Paderborn, Paderborn. 
[21] Yanikkaya, H. (2003) Trade Openness and Economic Growth: A Cross Country Empirical Investigation. Journal of Development Economics, 72, 57-89. https://doi.org/10.1016/S0304-3878(03)00068-3

[22] Kim, D.H., Lin, S.C. and Suen, Y.B. (2016) Trade, Growth and Growth Volatility: New Panel Evidence. International Review of Economics and Finance, 45, 384-399. https://doi.org/10.1016/j.iref.2016.07.006

[23] Choong, C.K. and Liew, V. (2009) Impact of Foreign Direct Investment Volatility on the Economic Growth of ASEAN-5 Countries. Economics Bulletin, 29, 1829-1841.

[24] Sothan, S. (2016) Foreign Direct Investment, Exports, and Long-Run Economic Growth in Asia: Panel Cointegration and Causality Analysis. International Journal of Economics and Finance, 8, 26-37. https://doi.org/10.5539/ijef.v8n1p26

[25] Dutta, C.B., Haider, M.Z. and Das, D.K. (2017) Dynamics of Economic Growth, Investment, and Trade Openness: Evidence from Bangladesh. South Asian Journal of Macroeconomics and Public Finance, 6, 82-104. https://doi.org/10.1177/2277978717695150

[26] Keshava, S.R. (2008) The Effect of FDI on India and Chinese Economy: A Comparative Analysis. Second Singapore International Conference on Finance, Singapore, 2 February 2008, 1-24. https://doi.org/10.2139/ssrn.1089964

[27] Hye, Q.M.A. and Lau, W. (2015) Trade Openness and Economic Growth: Empirical Evidence from India. Journal of Business Economics and Management, 16, 188-205. https://doi.org/10.3846/16111699.2012.720587

[28] Sharma, K. (2000) Export Growth in India: Has FDI Played a Role? Center Discussion Paper No. 816, Economic Growth Center, Yale University, New Haven.

[29] Ved, P. and Sudesh, P. (2007) An Empirical Investigation of the Causal Relationship between Openness and Economic Growth in India. Asian Economic Review, 49, 485-494.

[30] Le, T.-H., Kim, J. and Lee, M. (2015) Institutional Quality, Trade Openness, and Financial Development in Asia: An Empirical Investigation. Asian Development Bank, Philippines.

[31] Alesina, A. and Wacziarg, R. (1998) Openness, Country Size, and Government. Journal of Public Economics, 69, 305-321. https://doi.org/10.1016/S0047-2727(98)00010-3

[32] Jonsson, G. and Subramanian, A. (2000) Dynamic Gains from Trade: Evidence from South Africa. IMF Working Paper No. 00/45, International Monetary Fund, Washington DC. https://doi.org/10.5089/9781451846461.001

[33] Acaravci, A. and Ozturk, I. (2012) Foreign Direct Investment, Export, and Economic Growth: Empirical Evidence from New EU Countries. Romanian Journal of Economic Forecasting, 2, 52-67.

[34] Hussain, M.E. and Haque, M. (2016) Foreign Direct Investment, Trade, and Economic Growth: An Empirical Analysis of Bangladesh. Economies, 4, 7. https://doi.org/10.3390/economies4020007

[35] Hisarciklilar, M., Kayam, S., Kayalica, M. and Ozkale, N.L. (2006) Foreign Direct Investment and Growth in Mediterranean Countries. Sustainable Development and Adjustment in the Mediterranean Countries Following the EU Enlargement, FrancoAngeli, Milan, 395-420.

[36] Serge, C. and Yue, Y.X. (2010) The Relationship between Foreign Direct Investment, Trade Openness and Growth in Cote d'Ivoire. International Journal of Business and Management, 5, 99. https://doi.org/10.5539/ijbm.v5n7p99 
[37] Mottaleb, K.A. and Kalirajan, K. (2010) Determinants of Foreign Direct Investment in Developing Countries: A Comparative Analysis. ASARC Working Paper 2010/13. https://doi.org/10.1177/097380101000400401

[38] Osei, C. (2014) UK Foreign Direct Investment in Ghana: Determinants and Implications. Doctoral Thesis, Edinburgh Napier University, Edinburgh.

[39] GIPC (2017) Foreign Direct Investment Value. GIPC Quarterly Report, 13, 1-7

[40] Salem, F., Zahid, A. and Shoab, B. (2013) Impact of Inflation and Economic Growth and Foreign Direct Investment: Evidence from Pakistan. Interdisciplinary Journal of Contemporary Research in Business, 4, 236-244.

[41] Muritala, T. (2011) Investment, Inflation, and Growth: Empirical Evidence from Nigeria. Research Journal of Finance and Accounting, 2.

[42] Ghana Free Zones Authority, GFZA (2018) Ghana Moves up in FDI Investment Countries in Africa.

[43] Wafure, O.G. and Abu, N. (2010) Determinants of Foreign Direct Investment in Nigeria: An Empirical Analysis. Global Journal of Human Social Science, 10, 26-34.

[44] Owusu, M. (2017) The Determinants of Foreign Direct Investment Inflows in Ghana. Kwame Nkrumah University of Science and Technology, Kumasi.

[45] Majavu, A. and Kapingura, F.M. (2017) The Determinants of Foreign Direct Investment Inflows in South Africa: An Application of Johansen Co-Integration Test and VECM. Journal of Economics, 7, 130-143. https://doi.org/10.1080/09765239.2016.11907828

[46] Adi, A.A., Wobilor, A.K. and Adimani, W.E. (2015) The Determinant of Foreign Direct Investment and Its Effect on Economic Growth: Evidence from Nigeria. Journal of Economics and Sustainable Development, 6, 17-25.

[47] Dondashe, N. and Phiri, A. (2018) Determinants of FDI in South Africa: Do Macroeconomic Variables Metter? Munich Personal RePEc Archive (MPRA) Paper No. 83636 .

[48] Ebiringa, O.T. and Emeh, Y. (2013) Determinants of Foreign Direct Investment Inflow: A Focus on Nigeria. European Journal of Business and Management, 5, 41-52.

[49] Wasseja, M.M. and Mwenda, S.N. (2015) Analysis of the Determinants of Foreign Direct Investment in Kenya. Journal of Multidisciplinary Scientific Research, 3, 16-26.

[50] Ercakar, M.E. (2011) Growth, Foreign Direct Investment, Trade, and Inflation: An Empirical Application in Turkey. Middle Eastern Finance and Economics, 9, 137-147.

[51] Ali, K.H., Faki, S.M. and Suleiman, S.H. (2018) Determinants of Foreign Direct Investment Inflows in the Southern African Development Community (SADC) Member Countries. International Journal of Science and Business, 2, 616-623.

[52] Djokoto, J.G. and Dzeha, G.C. (2012) Determinants and Effects of Foreign Direct Investment in Ghana-Review of Literature. Developing Countries Studies, 2, 25-35.

[53] Ohazulike, O.K. (2012) The Effect of Exchange Rate Fluctuation, Infrastructures and Inflation on FDI Inflows into Nigeria (1986-2009). M.Sc. Thesis, Department of Banking and Finance, Nnamdi Azikiwe University, Awka.

[54] Omankhanlein, A.E. (2011) The Effect of Exchange Rate and Inflation on Foreign Direct Investment and Its Relationship with Economic Growth in Nigeria. Economics and Applied Information, 1, 5-16.

[55] Flora, P. and Agrawal, G. (2017) FDI and Economic Growth Nexus for the Largest FDI Recipients in Asian Emerging Economies: A Panel Co-Integration Analysis. In: 
International Business Strategy, Palgrave Macmillan, London, 261-275. https://doi.org/10.1057/978-1-137-54468-1 12

[56] STATA (2019) STATA LLC US Home Page. https://www.stata.com

[57] Vatcheva, P. and Lee, M. (2016) Multicollinearity in Regression Analyses Conducted in Epidemiologic Studies. Epidemiology: Open Access, 6, 227. https://doi.org/10.4172/2161-1165.1000227

[58] Yanique, C., Roland, C., Allan, W. and Anthony, W. (2012) Finance and Growth Causality: A Test of the Patrick's Stage-of-Development Hypothesis. International Journal of Business and Social Science, 3, 129-139.

[59] Berry, W.D. and Feldman, S. (1985) Multiple Regression in Practice (Quantitative Applications in the Social Sciences). SAGE Publications, Thousand Oaks.

[60] Kutner, M.H., Nachtsheim, C.J. and Neter, J. (2004) Applied Linear Regression Models. 4th Edition, McGraw-Hill Irwin, New York. 